Universidad de Lima

Facultad de Derecho

Carrera de Derecho

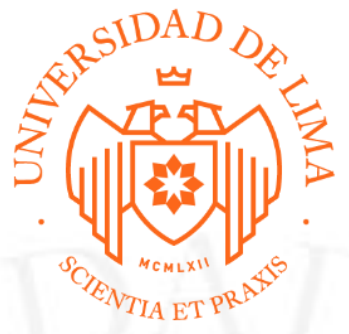

\title{
CIVIL: "VIOLENCIA FAMILIAR" Y \\ ADMINISTRATIVO: "PROTECCIÓN AL CONSUMIDOR"
}

Trabajo de suficiencia profesional para optar el Título Profesional de Abogado

\author{
Andrea Melissa Tello Espinoza
}

Código 20072579

Lima - Perú

Setiembre de 2019 


\title{
CIVIL: "VIOLENCIA FAMILIAR"
}

Materia: Violencia Familiar

Nro. de Expediente: № 11655-2013-0-1801-JR-FT-13

\section{RESUMEN}

El presente expediente trata sobre violencia familiar, en la modalidad de daño psicológico, el cual habría sido cometido por los demandados en agravio de ellos mismos y en agravio de sus menores hijas. En ese sentido, en el desarrollo del caso, se buscará esclarecer si los actos demandados y las pruebas adjuntadas por la fiscalía acreditan la existencia de violencia psicológica.

\section{ADMINISTRATIVO: "PROTECCIÓN AL CONSUMIDOR"}

\author{
Materia: Protección al Consumidor
}

Nro. de Expediente: $N^{\circ}$ 432-2013/CC2

\section{RESUMEN}

El presente caso trata sobre la presunta negativa a devolver el monto cancelado por unos pasajes aéreos, por parte de una de las empresas denunciadas; $y$, la falta de atención de reclamos, por parte de las otras empresas denunciadas. Por ello, en el desarrollo del mismo, se dilucidará si, efectivamente, estas obligaciones - recogidas en el Código de Protección y Defensa del Consumidor - fueron incumplidas. 